\title{
A new Gongylidiellum Simon, 1884 from the western Caucasus (Arachnida: Aranei: Linyphiidae)
}

\section{Новый вид рода Gongylidiellum Simon, 1884 с Западного Кавказа (Arachnida: Aranei: Linyphiidae)}

\author{
Andrei V. Tanasevitch*, Alexander V. Ponomarev** \\ А.В. Танасевич*, А.В. Пономарёв ${ }^{* *}$ \begin{abstract}
tanasevitch@gmail.com
Институт проблем экологии и эволюции РАН, Ленинский проспект, 33, Москва 119071, Россия.

** Institute of Arid Zones, Southern Scientific Centre, Russian Academy of Sciences, Chekhov str., 41, Rostov-on-Don 344006, Russia. Email: ponomarev1952@mail.ru

Институт аридных зон, Южный научный центр РАН, пр. Чехова, 41, Ростов-на-Дону 344006, Россия.
\end{abstract} \\ * Institute of Ecology and Evolution, Russian Academy of Sciences, Leninsky prospect, 33, Moscow 119071, Russia. E-mail:
}

KEY WORDS: spiders, Caucasus Major, new species, spider distribution.

КЛЮЧЕВЫЕ СЛОВА: пауки, Большой Кавказ, новый вид, распространение пауков.

ABSTRACT. A new species, Gongylidiellum caucasicum sp.n., is described from the Republic of Adygea, Russia, western Caucasus. It is most similar to the Anatolian-Caucasian G. orduense Wunderlich, 1995, but differs well by details of the genitalia in both sexes.

РЕЗЮМЕ. С Западного Кавказа (Республика Адыгея, Россия) описан Gongylidiellum caucasicum sp.n., наиболее близкий к анатолийско-кавказскому $G$. orduense Wunderlich, 1995, от которого хорошо отличается деталями строения гениталий обоих полов.

\section{Introduction}

This present paper continues the arachnological studies curried out in the small mountain Republic of Adygea, western Caucasus. Previously, 275 spider species, of which 77 are Linyphiidae, have been recorded from Adygea [Ponomarev et al., 2012, 2014; Ponomarev, Chumachenko, 2014]. The genus Gongylidiellum Simon, 1884 is represented there by two species: $G$. orduense Wunderlich, 1995 and G. vivum (O. PickardCambridge, 1875). Another, new species of this genus is discovered in the forest belt at 700-1800 $\mathrm{m}$ a.s.1. on the northern macroslope of the Caucasus Major Mountain Ridge. The new species is described below.

\section{Material and methods}

Specimens preserved in $70 \%$ ethanol were studied using a MBS-9 stereomicroscope. The epigyne was cleared with a hot $20 \%$ solution of $\mathrm{KOH}$. A Levenhuk C-800 digital camera was used as background for drawing the vulva. Images of multiple focal sections were combined using Helicon Focus image stacking software, version 5.1.
The type specimens are shared between the collections of the Zoological Museum of the Moscow State University, Moscow, Russia (ZMMU), the Muséum d'histoire naturelle, Geneva, Switzerland (MHNG) and the personal collection of Alexander Ponomarev (CP).

In the description, the sequence of leg segment measurements is as follows: femur + patella + tibia + metatarsus + tarsus. All measurements are given in $\mathrm{mm}$. Scale lines in the figures correspond to $0.1 \mathrm{~mm}$.

The formula of chaetotaxy means a number of dorsal spines on tibia I-IV.

The terminology of copulatory organs follows that of Merrett [1963] and Hormiga [2000].

The following abbreviations are used in the text and figures: APD - anterior radical process; CA claw-shaped apophysis; E — embolus; Fe - femur; $\mathrm{L}$ - lobe; $\mathrm{Mt}$ - metatarsus; $\mathrm{R}$ - radix; $\mathrm{SL}$ - small lobe; Ti — tibia; TmI — position of trichobothrium on metatarsus I.

\section{Description}

Gongylidiellum caucasicum sp.n. Figs 1-9.

2014 Erigoninae gen. sp. 1. - Ponomarev, Chumachenko: 99. HOLOTYPE: $\sigma^{7}$ (ZMMU), RUSSIA, western Caucasus, Republic of Adygea, Caucasian Nature Reserve, km 3 on road Guzeripl - Pasture Abago, $43.982222^{\circ} \mathrm{N} 40.153778^{\circ} \mathrm{E}, 1000 \mathrm{~m}$ a.s.1., mixed forest with Fagus orientalis \& Abies nordmanniana, litter, 12.VIII.2008, leg. Yu.A. Chumachenko.

PARATYPES: 9 우 (ZMMU), 2 우 (MHNG), same locality, 12.VI.-3.X.2008, leg. Yu.A. Chumachenko; 2 우 (ZMMU), same locality, 28.IX.-13.X.2009, leg. Yu.A. Chumachenko; 2 우 (CP), same locality, summer 2004, leg. Yu.A. Chumachenko; 2 우 (CP), same locality, 2.VI.2004, leg. Yu.A. Chumachenko; 2 + $($ (ZMMU), 2 oᄋ (CP), CNR, km 7 of road Guzeripl - Pasture Abago, $43.973361^{\circ} \mathrm{N}$ $40.198222^{\circ} \mathrm{E}, 1400 \mathrm{~m}$ a.s.1., mixed forest with Fagus orientalis \& 


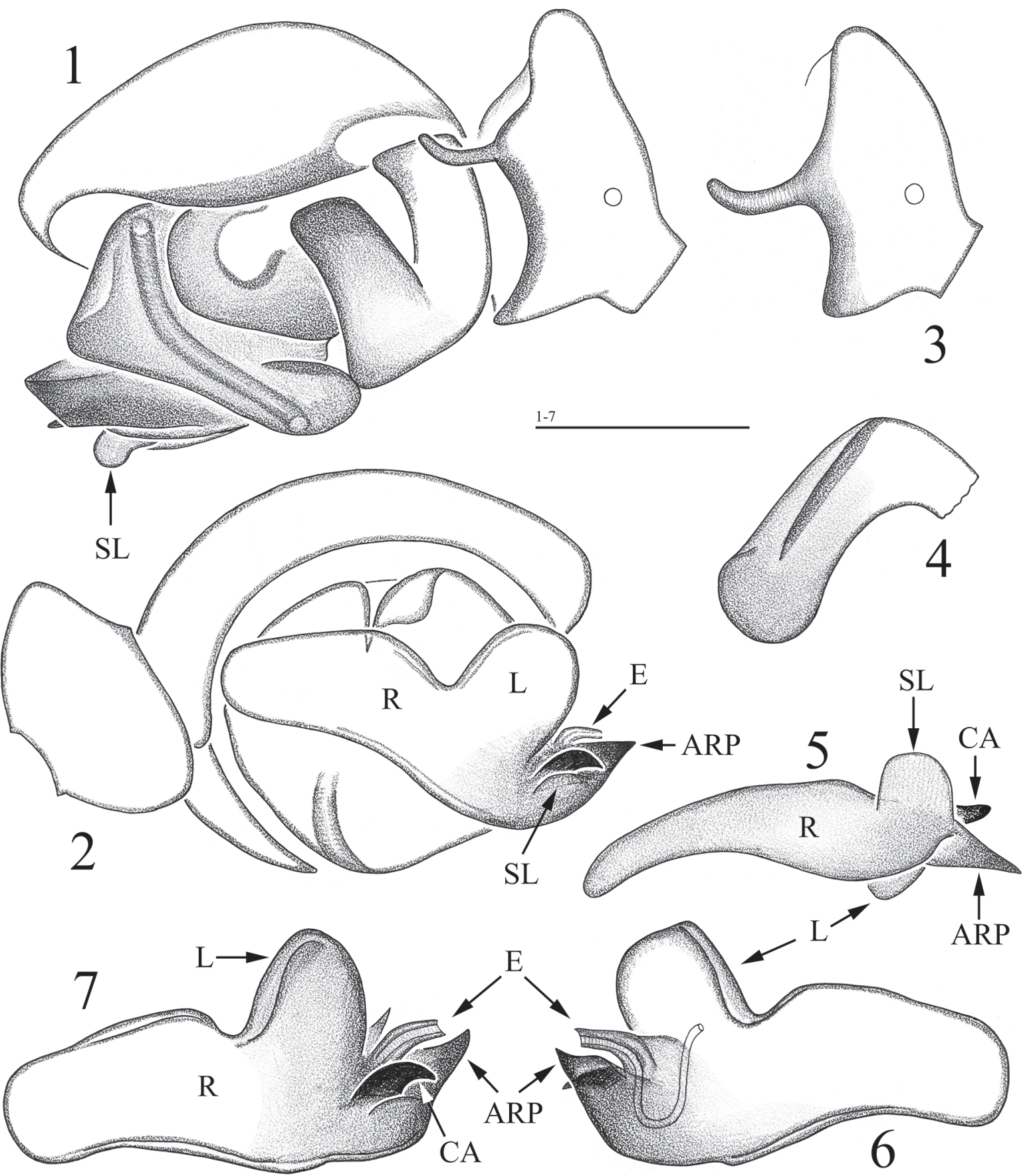

Figs 1-7. Holotype, palp of Gongylidiellum caucasicum sp.n.: 1, 2 - left palp, retro- and prolateral views, respectively; 3 - palpal tibia, lateral view; 4 - distal suprategular apophysis; 5-7 - embolic division.

Рис. 1-7. Голотип, пальпа самца Gongylidiellum caucasicum sp.n.: 1, 2 - правая пальпа, про- и ретролатерально; 3 - голень пальпы, вид сбоку; 4 - дистальный отросток супратегулюма; 5-7 - эмболюсный отдел.

Abies nordmanniana, litter, 29.V.2012, leg. Yu.A. Chumachenko; 2 우 (MHNG), Guzeripl, $43.996111^{\circ} \mathrm{N} 40.141000^{\circ} \mathrm{E}, 700 \mathrm{~m}$ a.s.1., in soil \& litter, 3.VI.2005, leg. Yu.A. Chumachenko; 1 o (ZMMU), Maikop Distr., Lagonaki Plateau, environs of Azishskiy Pass, $44.075861^{\circ} \mathrm{N} 40.013417^{\circ} \mathrm{E}$, ca $1810 \mathrm{~m}$ a.s.l., coniferous forest with Abies nordmanniana on slope, 16-23.VII.2014, leg. A. Ponomarev.
NAME. The specific name is an adjective, meaning the terra typica of the new species.

DESCRIPTION. $\sigma^{7}$ (holotype). Total length 1.38 . Carapace 0.68 long, 0.53 wide, pale yellow, unmodified, sulci absent. Chelicerae 0.28 long, a small mastidion present. Legs mostly broken off, pale yellow. Fe I, 


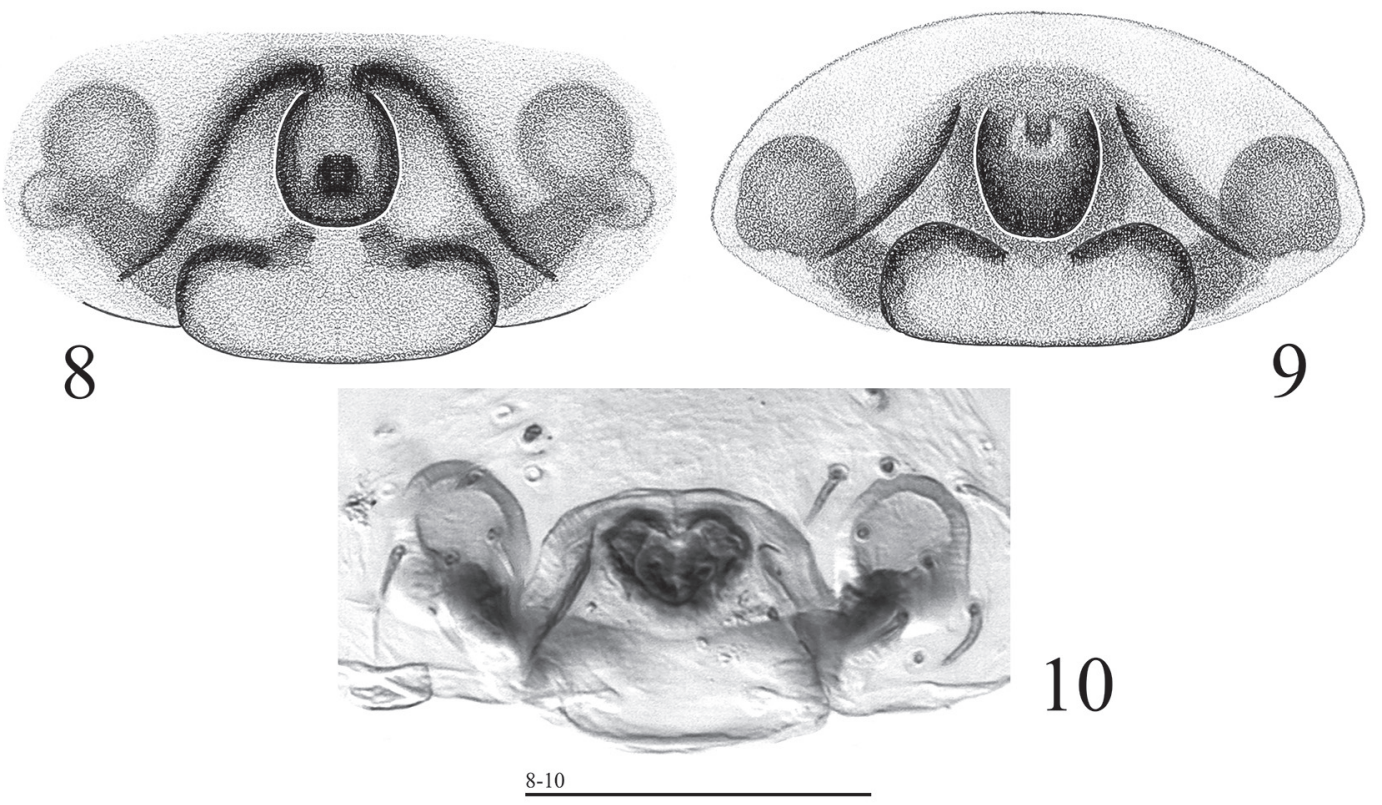

Figs 8-10. Epigyne of Gongylidiellum caucasicum sp.n.: 8, 9 - ventral and ventro-caudal views, respectively; 10 - cleared epigyne, ventral view.

Рис. 8-10. Эпигина Gongylidiellum caucasicum sp.n.: 8, 9- вид снизу и вид снизу и сзади; 10 - просветленная эпигина, вид снизу.

0.50. Leg IV, 1.53 long $(0.45+0.18+0.30+0.35+$ 0.25). Chaetotaxy: see $q$ description. TmI unknown. Metatarsi IV without trichobothrium. Palp (Figs 1-7): Tibia slightly elongated, with a narrow, long, curved, retrolateral apophysis. Paracymbium simple, U-shaped, its distal lobe wide, strongly sclerotized. Distal suprategular apophysis straight, with almost parallel edges. Radix in front of embolic part with a large and rounded lobe. Anterior radical process wedge-like narrowing distad. Distal part of embolic division with a claw-shaped apophysis and a small, flat semi-lunar outgrowth. Embolus shot, curved, poorly sclerotized. Abdomen 0.80 long, 0.45 wide, pale grey.

q. Total length 1.50. Carapace 0.65 long, 0.53 wide, pale brown, unmodified. Chelicerae 0.33 long, mastidion absent. Leg I, 1.76 long $(0.50+0.18+0.53+0.30+$ $0.25)$, IV 0.63 long $(0.50+0.15+0.43+0.30+0.25)$. TmI, 0.36. Abdomen 0.85 long, 0.60 wide, grey. Epigyne (Figs 8-10): Lateral walls incline, making aperture triangular; anterior wall (= ventral plate) with a large rounded outgrowth and a black pit on it frontal face.

VARIABILITY. $\sigma^{7}$ paratype somewhat darker than holotype. + +o coloration varied from yellow to brown (carapace) and from almost white to dark grey (abdomen).

TAXONOMIC REMARKS. The new species seems to be most similar to the Anatolian-Caucasian G. orduense Wunderlich, 1995 [see Wunderlich, 1995; Tanasevitch, 2011], but the $\sigma^{7}$ differs by the curved prolateral outgrowth of the palpal tibia, the straight distal suprategular apophysis, non-narrowed distal part of the paracymbium, as well as the presence of a large rounded lobe on the embolic division. The $q$ of the new species is clearly distinguished by a small and rounded outgrowth of the anterior wall of the vulva, which is well protruded and drop-shaped in G. orduense.

ACKNOWLEDGEMENTS. The authors are grateful to Yuri A. Chumachenko (Maikop, Russia) for provided most of the material, also to Sergei I. Golovatch (Moscow, Russia) for checking English of an advanced draft.

\section{References}

Hormiga G. 2000. Higher level phylogenetics of erigonine spiders (Araneae, Linyphiidae, Erigoninae) // Smithsonian Contributions to Zoology. No.609. S.1-160.

Merrett P. 1963. The palpus of male spiders of the family Linyphiidae // Proceedings of the Zoological Society of London. Vol.140. P.347-467.

Ponomarev A.V., Chumachenko Yu.A. 2014. [Spiders (Aranei) in herpetobiont mesofauna of the northwestern Caucasus] // Yug Rossii: ecologiya, rasvitie. No.2. P.95-101 [in Russian, with English summary].

Ponomarev A.V., Kovblyuk N.M., Chumachenko Yu.A., Volkova D.D. 2012. [Preliminary data on the fauna of spiders (Aranei) of the Republic of Adygea] // Matishov G.G., Khunagov R.D. (eds.). Sotsial'no-gumanitarnye i ekologicheskie problemy razvitiya sovremennoi Adygei. Rostov-on-Don: Russian Academy of Sciences, South Science Center Publishers. P.447-481 [in Russian].

Ponomarev A.V., Shapovalov M.I., Ivliev P.P. 2014. [New data on the fauna of spiders (Aranei) in the South of the European part of Russia] // Vestnik Adygeyskogo Gosudarstvennogo Universiteta. Series 4: Estestvenno-matematicheskie i tekhnicheskie nauki. Issue 2 (137). P.54-60 [in Russian].

Tanasevitch A.V. 2011. On linyphiid spiders (Araneae) from the Eastern and Central Mediterranean kept at the Muséum d'histoire naturelle, Geneva // Rev. suisse Zool. T.118. Fasc.1. P.49-91. 
Wunderlich J. 1995. Beschreibung bisher unbekannter Arten der Baldachinspinnen aus der östlichen Mediterraneis (Arachnida: Araneae: Linyphiidae) // Beiträge zur Araneologie. Bd.4. S.655686.

Responsible editor K.G. Mikhailov 